\title{
ナビゲーション脳神経外科手術の現況と展望
}

\author{
梶田 泰一1)，森 健策 ${ }^{2}$ ，林 雄一郎 ${ }^{2}$ ，若林 俊彦1)，吉田 純 ${ }^{3)}$ \\ 1）名古屋大学大学院医学系研究科脳神経外科，2）同 情報科学研究科，3）中部労災病院脳神経外科
}

\section{The Current Status and Perspective of Navigation Neurosurgery}

\author{
Yasukazu Kajita, M.D. ${ }^{1)}$, Kensaku Mori, M.D. ${ }^{2)}$, Yuichiro Hayashi, M.D. ${ }^{2)}$, \\ Toshihiko Wakabayashi, M.D. ${ }^{1)}$, and Jun Yoshida, M.D. ${ }^{3)}$ \\ 1) Department of Neurosurgery, Nagoya University, Graduate School of Medicine, 2) Nagoya University, Graduate School of Infor- \\ mation Science, 3) Department of Neurosurgery, Chubu Rousai Hospital
}

Neuronavigation has become an established technology to provide objective data on localization in 3D space. In the surgery for lesions near the eloquent area, obtaining a functional image including functional magnetic resonance imaging (fMRI) and tractography is important for making presurgical planning. Navigation technology is essential to perform the operation according to the pre-surgical planning. The surgeons, however, must realize that it does not always correlate well with real localization accuracy. Error analysis includes image distortion, fiducial localization error and registration error, which can all be minimized. Brain shift, caused by the loss of cerebrospinal fluid and tumor resection, is a major problem negatively affecting navigation accuracy. Intraoperative imaging to obtain updated anatomic image data overcomes the problem of brain shift, but the equipment is not so easily installed into the operating room. The development of computer technology is expected to solve this problem in the future.

The following are some perspectives of neuronavigation with the advance of computer technology: The 3D virtual image will be more intuitive to navigate for surgeons. The development of navigation workstations could have the potential to interpret the real surgical view and provide an automated nomenclature of brain structure to surgeons. Robotic systems might facilitate the navigation procedure to enhance the localization accuracy. Networked neuronavigation is a future direction to assist in operations performed at remote hospitals using navigation image software that utilizes network technology. Finally, to improve the navigation procedure amongst the operation team as well as surgeons, environmental navigation could be proposed to monitor the operative staff and to show the optimal arrangement in the operating room.

(Received February 18, 2013 ; accepted March 1, 2013)

Key words : neuronavigation, computer technology, robotic surgery

Jpn J Neurosurg（Tokyo）22:510-518, 2013

\section{はじめに}

脳神経外科手術が従来困難とされたのは，1）脳の機

能局在が不明のまま，脳を手術操作したことで予期せぬ

後遺症が出現したこと，2）脳神経外科手術は，脳内の
きわめて狭く，重要な血管や神経に囲まれたスペース内 での手術操作技術が要求されたことにある。顕微鏡の導 入により，䋊細な手術操作が可能となり，手術成績は格 段に向上したが，脳深部病変では，顕微鏡視野はさらに 狭くなり，オリエンテーションを失うことも多い。脳神

連絡先：梶田泰一， $\bar{T} 466-8550$ 名古屋市昭和区鶴舞町 65 名古屋大学医学部脳神経外科

Address reprint requests to: Yasukazu Kajita, M.D., Department of Neurosurgery, Nagoya University, Graduate School of Medicine, 65 Tsurumai, Shouwa-ku, Nagoya-shi, Aichi 466-8550, Japan 


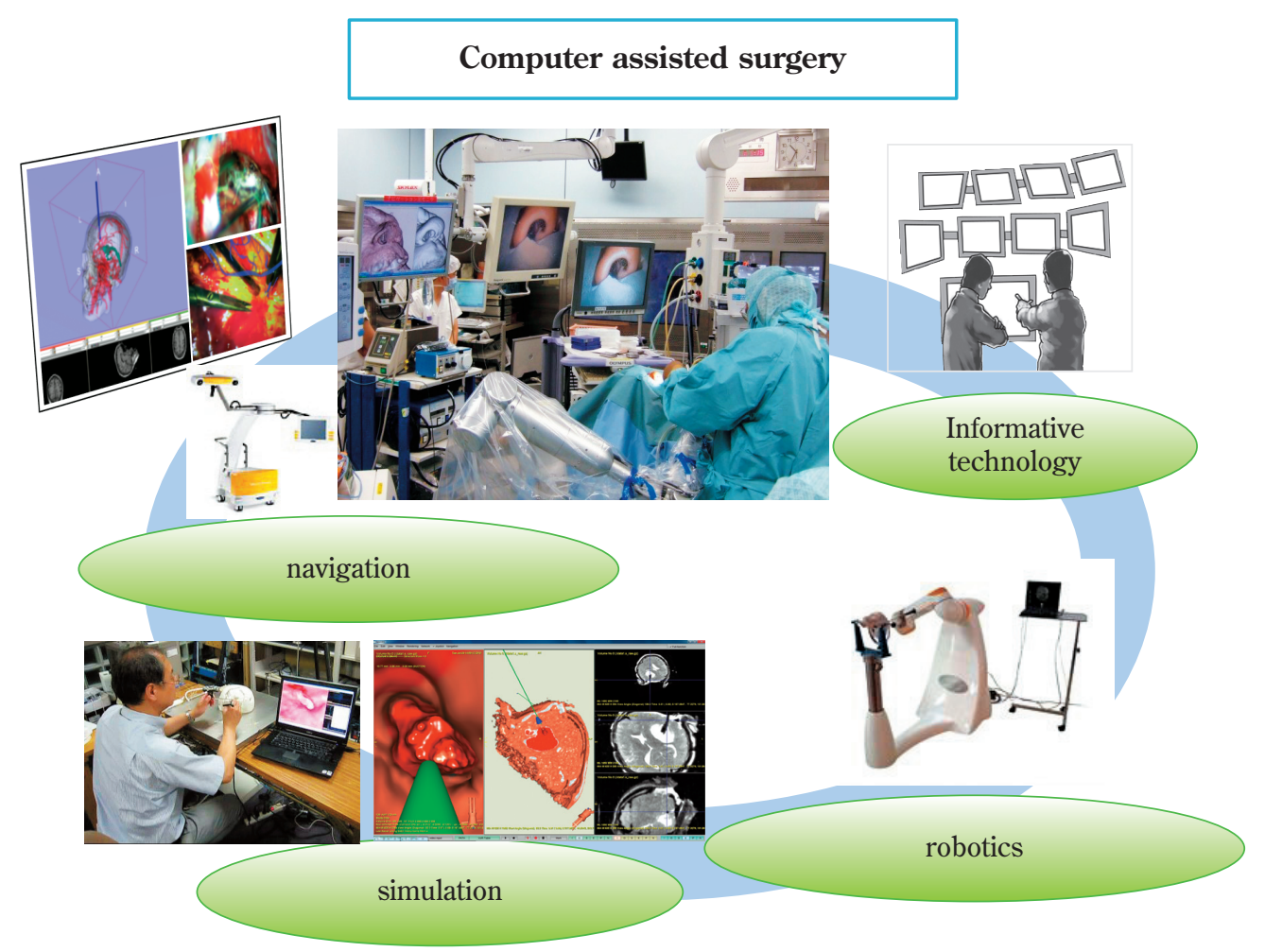

Fig. 1 The development of neuronavigation surgery and computer assisted surgery

経外科手術を，できるだけ低侵襲に，最適にアプローチ するためには，手術中にリアルタイムに位置情報を提供 するナビゲーションシステムは，きわめて有用である. 1986 年, 他領域に先駆けて, 渡辺らは脳神経外科用多関 節アーム式ニューロナビゲーションを開発した。その後, 位置情報の取得方法（トラッキングシステム）として, 光学式, 磁気式が開発され, 現在はその位置精度の高さ により，光学式が主流となっている.

1998 年, 伊関ら ${ }^{12)}$ が本誌にナビゲーションシステムの 将来展望を, 既述している。本稿では, それ以降のナビ ゲーションの発展を中心に報告する（Fig. 1)．最近の最 も大きなニューロナビゲーションの発展は, 画像技術の 進歩に伴い多くの機能情報を統合したナビゲーション画 像の作成と, 3D virtual 画像に代表される術者に直感的 に提示する画像技術の開発にある。 また, 手術の進行に 伴う脳偏位によりニューロナビゲーション位置精度が正 確性を失う問題を解決するために, 術中画像を撮像し, ナビゲーション画像をアップデートしていく試みであ $3^{13) 16(22) 26)}$. 術中画像として, computed tomography (CT), magnetic resonance image（MRI）, 超音波画像, 赤外線カメラ装置などが導入されている20).

ニューロナビゲーション手術の将来展望では, コン
ピューター技術の進歩に合わせ，より高度化されたナビ ゲーションワークステーションの開発，ロボット技術に 代表されるコンピューター支援技術やネットワーク技術 の導入が期待されている.

\section{ニューロナビゲーションの現況}

ニューロナビゲーション手術のワークフローは，1） ナビゲーション画像の取得，2）手術計画の作成，3）ナ ビゲーション画像空間と手術実空間とのレジストレー ション，4）ナビゲーション手術である.

\section{1 ナビゲーション画像の取得}

ナビゲーション画像の基本となるのは，手術実空間と のレジストレーションに必要な fiducial marker をつけて 撮像される CT, MRI の解剖学的画像である. 加えて, 重要な脳機能近傍の病変に対する脳神経外科手術に対し ては，functional magnetic resonance image（fMRI）にて 脳皮質を局在化し， diffusion tensor imaging（DTI）撮像 による fiber tracking 画像を作成し, 病変との位置関係を 知る必要がある。脳腫瘍手術においては，腫瘍の境界や 性状を知る指標として, MR spectroscopy や, fludeoxyglu- 


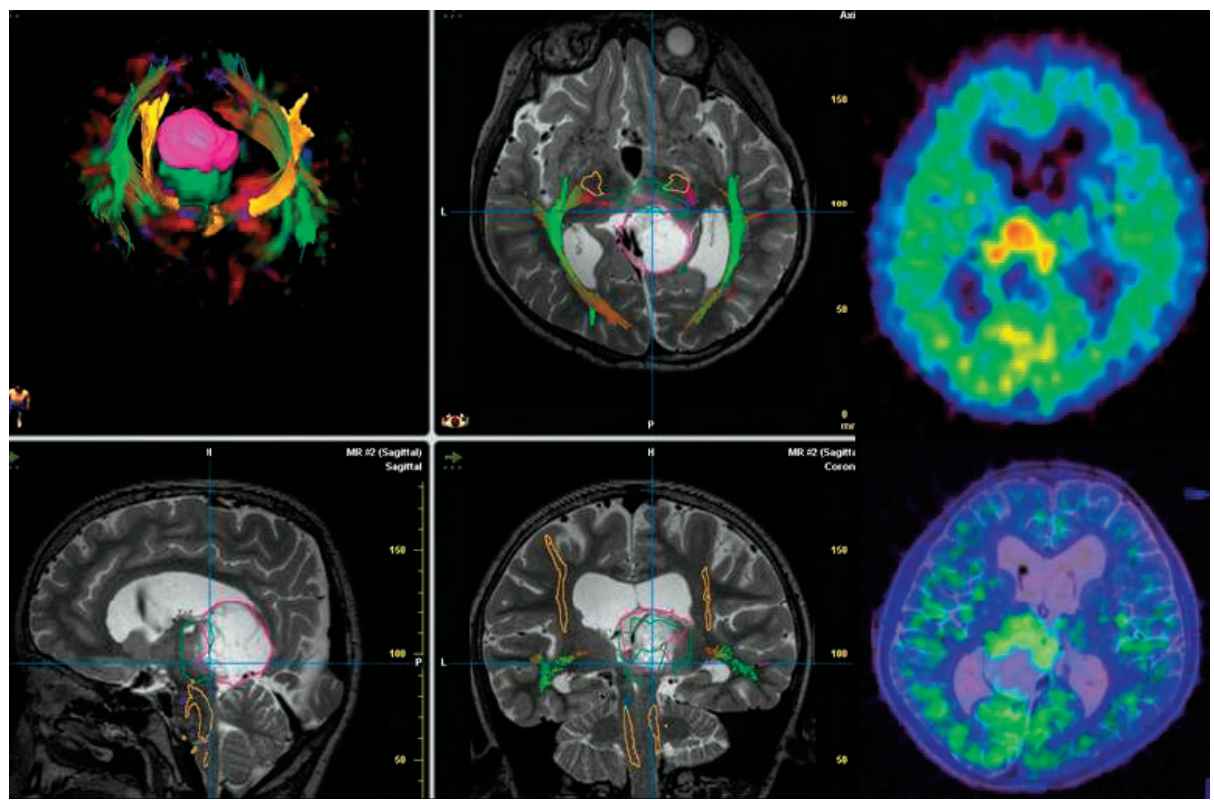

Fig. 2 A navigation image with integrated anatomical and functional image

cose $\left(\mathrm{F}^{18}\right)$ positron emission tomography (FDG-PET) や, methionine PET も有用である. 的確な手術計画を作 成し，安全に手術を進行するため，各施設で利用できる 多くの機能画像を取得しておくことが重要である.今後, 脳画像技術の進歩に合わせて, ナビゲーション画像の向 上が期待される。

\section{2 手術計画の作成}

前述した脳機能画像を解剖学的画像に統合して, 最適 な手術計画を作成する（Fig. 2)。ただ，脳機能画像に基 づいて手術を実施するには, 少し注意を要する. fMRI は, echo-planar imaging（EPI）法にて撮像されるが, その撮 像法による画像の歪み（特に下側頭回や前頭葉で強い） が出たり，特定のタスク（言語マッピングなど）により 活性化された脳機能部位は, 実際の脳機能部位より広範 囲であるかもしれないことを留意しておいたほうがよ い. PET, DTI は, 脳腫瘍の性状や錘体路や弓状束など の重要な線維をそれぞれ描出するが, 解像度が低い.

Fiber tracking image は, 汎用されているニューロナビ ゲーションシステムのワークステーションで作成可能で あるが，使用されるアルゴリズムやパラメーターで image に差が生じる. Fiber が交差するところでは, 過小 評価となるかもしれない21). 一方, fiber tracking image の妥当性を, 術中に電気生理学的に検証している論文も ある ${ }^{37)}$ 。

近年, $3 \mathrm{D}$ 画像の発達はめざましく「高速, 高精度可
視化手法（高速ボリュームレンダリング）」「各種モダリ ティ画像間のレジストレーション手法」「3D 画像変形処 理手法」, 3D 画像から手術を行ううえで必要な種々の情 報を取り出す「3D 画像解析技術」などますます高度化 している ${ }^{29)}$ (Fig. 3). 精密な血管や神経の高精細画像が可 能になったことにより，腫瘍と血管，神経の位置関係を 明瞭に重畳した 3D ヴァーチャル画像は，術者が直観的 に理解しやすく大変有用である.

\section{3 ナビゲーション画像空間と手術実空間のレジ ストレーション}

ナビゲーション画像空間を, 手術実空間にレジスト レーションするには，1）マニュアルで, fuducial marker を使い, paired-point で，2）自動アルゴリズムを使って 行う方法がある。マニュアルレジストレーションは，術 者が精度を高めるために，レジストレーションの最適化 が可能である. 加えて, surface marker レジストレーショ ンを追加することで, 位置精度の誤差が減少する.トラッ キングシステムは, 光学式, 磁気式, 多関節式があり, それぞれに利点と発展性がある。

\section{1. 光学式}

赤外線を利用して位置情報を知るシステム。多くは, カメラユニットより赤外線を発光し, 手術器具に取り付 けた反射素材で反射された赤外線を charge coupled device（CCD）カメラで認識する。位置精度は，最も正 確であり汎用されている。ファントム研究のナビゲー 

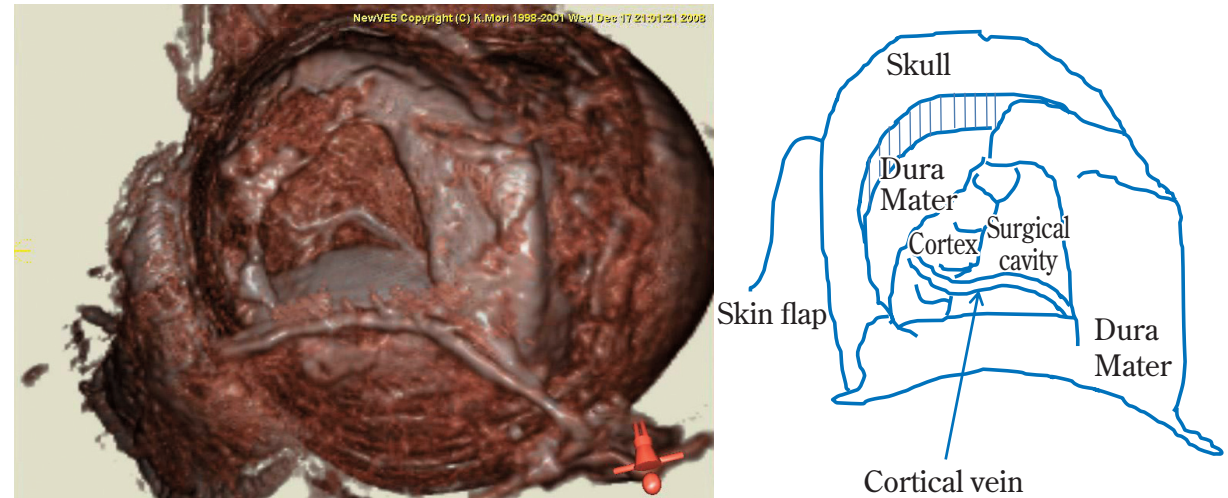

Fig. 3 Virtual 3D image provided by the New Virtual Endoscope

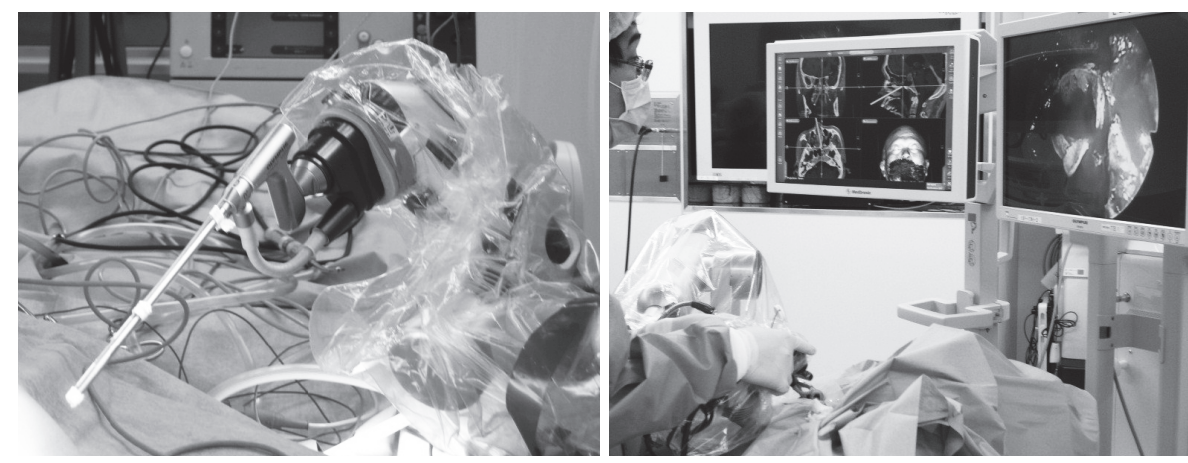

Fig. 4 Magnetic neuronavigation guided endoscopic surgery for pituitary adenoma

ションシステム位置精度で, Polaris Spectra を用いた光 学式トラッキングでは，0.25〜 0.3 mm，Auroraを使った 磁気式トラッキングでは，0.9 1.5 mm の誤差であっ $た^{38)}$.

\section{2. 磁気式}

手術操作空間内に磁界を発生させ，手術器具に磁気セ ンサを装着させることで位置情報を取得する。トラッキ ング可動領域が狭いことや，周囲の金属により磁場の歪 みが生じ，位置精度に影響が出る問題がある。一方，専 用器具が小型で軽量であり, 光学式と違い, 手術器具が 体内に入っても，トラッキングは可能である（Fig. 4). 実内視鏡ビデオフレーム画像と三次元 MR 画像から生 成されるヴァーチャル内視鏡画像との間の画像間類似度 が最も高くなるヴァーチャル内視鏡画像の描画パラメー 夕ーを連続的に求めることで，実内視鏡のカメラの動き を推定したり，内視鏡先端に取り付けた磁気センサーに て，磁気の歪みをリアルタイムに測定，補正することで さらに正確なナビゲーション機能をもたせる技術開発が 進んでいる ${ }^{15) 18)}$.

\section{3. 多関節式}

可動性のアームの先端にプローブを装着し，プローブ が動いた時に，アームの角度から位置を算出するシステ ム。主にナビゲーション技術開発の初期に設計された。 しかしながら，多関節式トラッキングシステムは，術前 計画の位置情報に基づいて自動的に多関節アームを調節 しナビゲートする（ロボット技術）ことが可能である。 詳細は，ナビゲーションの展望の項で後述する.

脳神経外科医が，ニューロナビゲーションを使用して 手術をする際に，位置精度誤差の要因を把握しているこ とは重要である。位置精度の䛊差をきたす原因としては, センシング位置と対象位置精度, 器具の製造精度, CT ・ $\mathrm{MRI} ・ \mathrm{X}$ 線画像などのスライス厚・画像の歪み，ヒュー マンエラーに関する誤差要因，器具取り付け，赤外線に 起因する問題，パッシブマーカーの再使用などが挙げら れる ${ }^{42)}$ 。術者は，許容できない位置誤差が出た場合に， 上述した誤差要因を検討し，精度が高いナビゲーション 手術を心がける必要がある。 
Real time virtual deformation following the tumor resection and intraoperative MRI

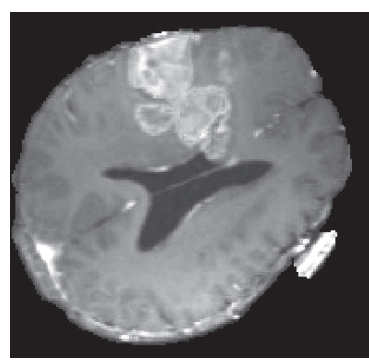

Preoperative

MRI

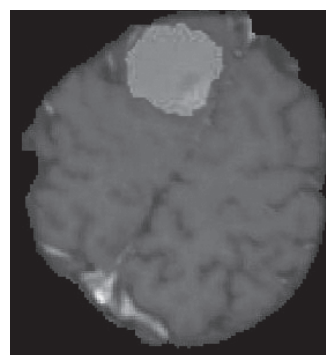

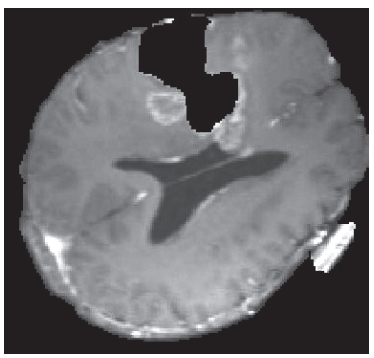

Before virtual deformation

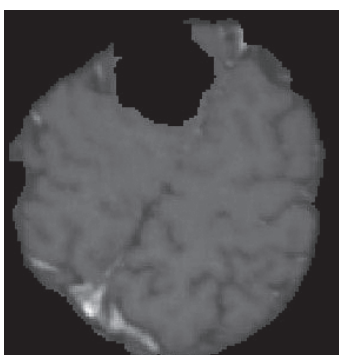

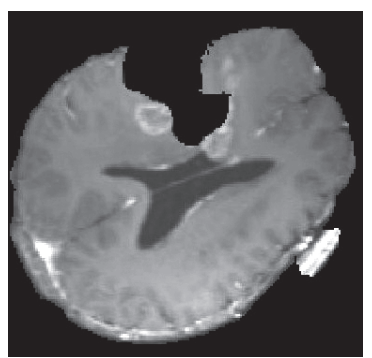

After virtual deformation

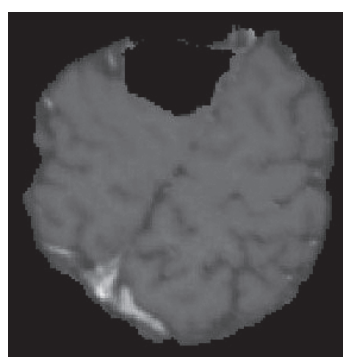

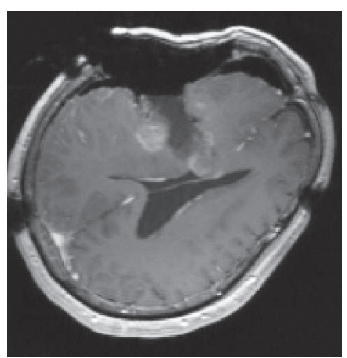

Intraoperative MRI

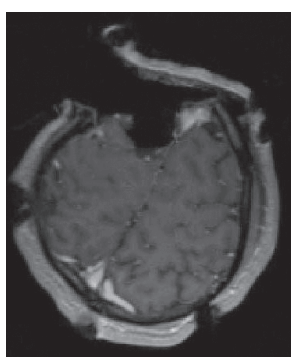

Fig. 5 Comparison between virtual deformity of a 3D image following tumor resection and the real intraoperative magnetic resonance image

\section{4 ナビゲーション手術}

ナビゲーションを使い, 術前計画に沿つて手術を進め る中で，開頭後に，髄液漏出等に伴う脳偏位により，ナ ビゲーション誤差が生じてくることが多い2)318)31). Nim-

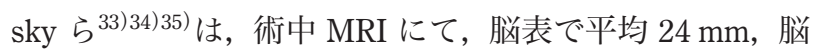
深部で平均 $3 \mathrm{~mm}$ の脳偏位や, 術中や脳腫瘍摘出後に錐 体路が移動することを報告している。したがって，術前 ナビゲーション画像を盲目的に信用して, 手術を行うこ とは危険である. 画像解像度が高い術中 MRI によるナビ ゲーション画像のアップデートは, 誤差を解消する最も 確実な方法であるが，汎用性に乏しい39)。超音波画像の 進歩により，超音波画像を用いたアップデートの報告が 増加しているものの, 画質に限界がある。術中画像を用 いずに，バネ理論に基づいたリアルタイム脳変形画像技 術 (4D 画像) による脳偏位のシミュレーションや脳偏 位を最小化するフェンスポスト法等のさまざまな工夫が なされている17)27) (Fig. 5).

\section{ニューロナビゲーションの展望}

今後のナビゲーション手術の発展にまず期待するもの は, 術中脳偏位に伴う位置精度誤差の解決である。前述 したように術中 MRI によるアップデートは, 最も確実で あるが，リアルタイムの補正や装置の導入には限界があ る4)5)6)9). 将来, 術中画像に頼らないコンピューター技
術を用いての補正が望まれる。今井ら ${ }^{11)}$ は，有限要素法 解析に基づく変形画像技術を用いて実画像を極力追従す るナビゲーション画像を開発する取り組みをしている。

将来展望としては，1）intelligent surgical assistance,

2）ネットワークナビゲーション手術，3）ロボット技術 と連携, 4) environmental navigation などの方向性がある.

\section{Intelligent surgical assistance}

磁気式ナビゲーションの項で前述したように, 術野画 像の解剖学的構造をコンピューターが自動解析し, 的確 な情報を提示するとともに，術前シミュレーションに合 わせて，術者をナビゲートするシステムである。術野の 解剖学的情報を, 文字情報で情報提示し, かつ, 術中に 生じる電気生理学的, 病理学的情報を統合することで, より的確なナビゲートを行う ${ }^{30)}$ 。気管支構造や，腹腔内 臓器においては, すでに臨床応用され, 気管支ファイバー 検査等において，検査医師が病巣気管支にファイバーを 正確に誘導している ${ }^{25)}($ Fig. 6)。伊関らの論文にある active navigation も同じ方向性を示唆していると思われ る.

さまざまなコンピューター外科技術は，外科医のシ ミュレーションやトレーニングに大いに貢献している. コンピューターグラフィック画像によるヴァーチャルト レーニング技術は, 外科医の縫合, 切除などの手術操作 を実手術に近く再現している。脳神経外科手術において 
Intelligent surgical assistance
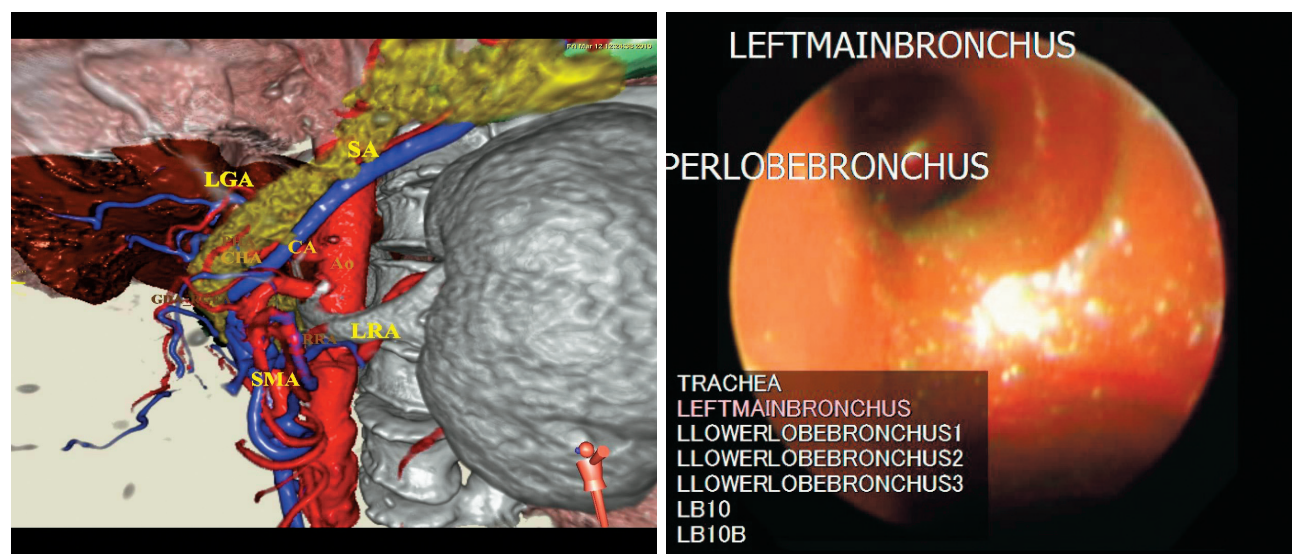

Fig. 6 Automated nomenclature of upper abdominal arteries for displaying anatomical names on virtual bronchofiberscope and laparoscopic images

も，3D ヴァーチャル画像生成技術は，患者個々の術前 画像から立体ファントムを作成し手術計画をシミュレー ションすることや，若手脳外科医のトレーニングに役 立っている ${ }^{30)}$. 今後, 術前シミュレーションした四次元 画像をナビゲーション画像に使用して，術前シミュレー ションと術中ナビゲーションがシームレスにつながるこ とも期待される。

\section{2 ネットワークナビゲーション手術}

ナビゲーション画像に，多くの手術支援情報を統合し て，手術支援 3D 画像を作成することを，各病院のワー クステーションで実施することは困難である。このよう な高度ナビゲーションにおいては，cloud 技術を用いれ ばホストコンピューターサーバーで作業可能である。ま た，ネットワーク化した病院においては，遠隔地の手術 症例に対して熟練医師が術前手術計画を作製し，術中に ナビゲーション画像を用いて遠隔支援（headquarter 支 援）できる. Hayashi ら ${ }^{10)}$ は，3D 画像生成ソフトウェア (New Virtual Endoscope) にナビゲーション画像を使っ て，遠隔手術支援するためのコンピューターネットワー ク分散強調技術を実装している ${ }^{10)}($ Fig. 7). 吉田らは，今 後, 手術支援情報が増加するに伴い, 術者が手術操作と 並行して, 多数の手術支援情報を的確に判断し, 手術計 画をアップデートする負担を軽減する必要があると考え た。手術室とは別に手術計画作成ワークステーションな どの設備を備えた手術戦略室を設け，手術室，放射線部， 脳神経外科医局間を結び，手術支援情報ネットワークシ ステム（Nagoya Surgical Information Network System）を 構築した ${ }^{18)} 41$ ) . さらに, 最先端の $3 \mathrm{D}$ 画像解析技術を有 する情報科学研究科, 保健学科放射線技術科にネット
ワークを拡充し，ヴァーチャル 3D 画像により，手術支 援を得るネットワークを構築している ${ }^{19)}$ 。このようにナ ビゲーションに IT 技術を実装することにより，困難な 手術症例に対しリアルタイムに多地点で遠隔手術支援 や，新しい手術手技の開発を共同で行うことが実現す $ろ^{17)}$.

\section{3 ロホホット技術との連携}

多関節アーム式ナビゲーションにおいては，術前計画 の位置情報に基づいて，多関節アームを自動的に操作し てナビゲーションするロボット技術の導入が可能であ る 23 32) 1990 年代より，外科治療をナビゲートするロ ボット技術の開発は始まり $\left.{ }^{44)} 45\right)$, 整形外科や泌尿器科領 域等においては，その導入の簡便さにより，病変組織の 生検等をナビゲートする手術ロボットが，臨床応用され ている ${ }^{7)}$ 14) 。高精度な局在化が要求される脳神経外科手 術では，CT や MRI により術前計画を作成し，6 自由度 の多関節アームでナビゲートする NeuroMate robot が, 欧米を中心に，定位脳手術などに広く臨床応用されてい る ${ }^{124)}$ (Fig. 8)。ささらに，ロボット技術に光学式トラッキ ングと組み合わせたハイブリッド式ナビゲーション技術 の報告もある ${ }^{43)}$.

\section{Environmental surgical assistance}

外科手術は，術者とともに，看護師，助手を含めた手 術スタッフのチーム医療である。脳神経外科手術をより 円滑に進めるため，術野のナビゲーションのみならず， 手術室全体を統括ナビゲーションする取り組みが, environmental surgical assistance である。手術室内に設置さ れた複数のカメラでスタッフの動き，手術支援装置の配 
Illustration of the proposed headquarter system with computer network technology
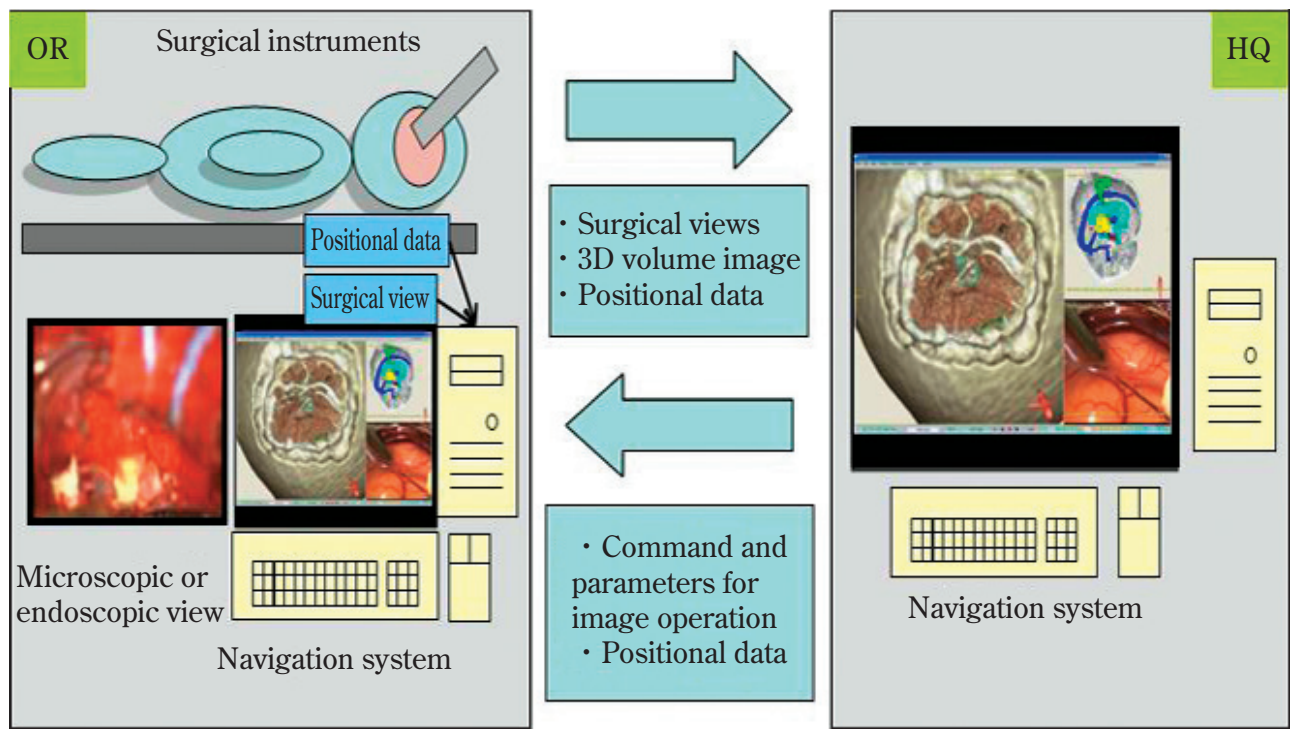

Fig. 7 Surgical assistant headquarter system for appending communication and collaborating with the imaging software providing the surgery assisted $3 \mathrm{D}$ virtual image

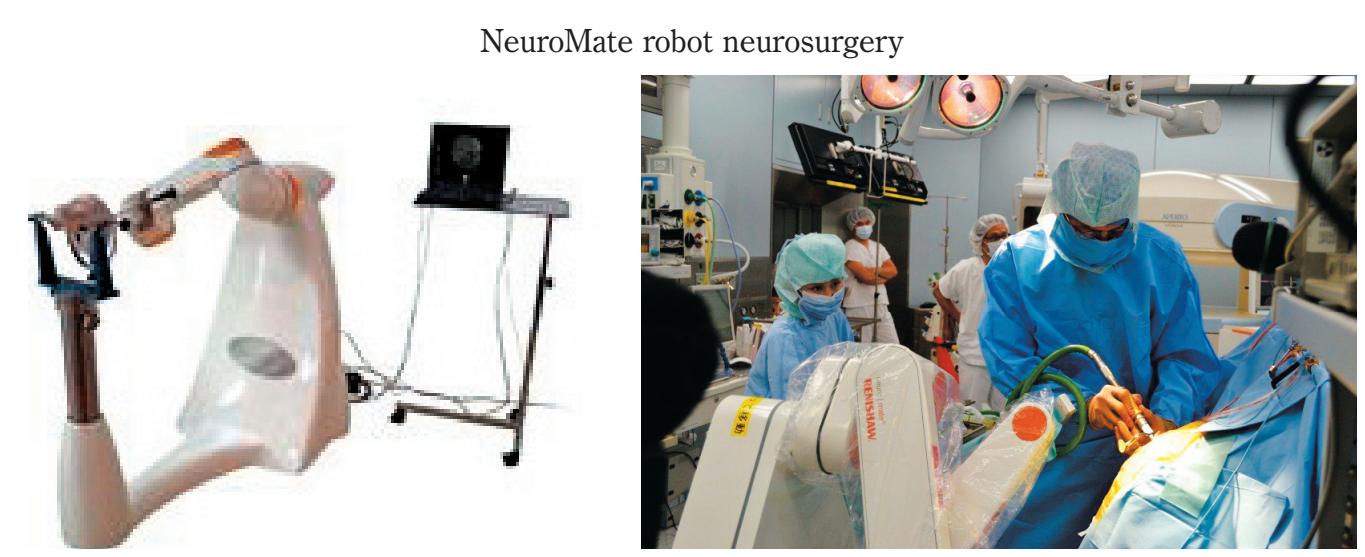

Fig. 8 The NeuroMate robot and stereotactic surgery navigated by the NeuroMate

置などを監視する。手術室全体をモニタリングしたデー 夕解析から, 最適な手術環境をナビゲートしたり, 手術 室内でスタッフの異常な動きを察知して, より安全に脳 神経外科手術が実施される。鈴木ら ${ }^{40)}$ は, その先駆けと して, PC 1 台で 8ch の映像・音声情報を十分な画質で 録画し，解析するシステムを開発している ${ }^{40)}$.

\section{結 語}

ニューロナビゲーションの現況を報告するとともに, 今後の展望を述べた。現在, ニューロナビゲーションは, 必須の手術支援技術となっている。コンピューター技術
の開発に併せて，ニューロナビゲーションの発展が期待 されている。

\section{文 献}

1) Benabid AL, Cinquin P, Lavalle S, Le Bas JF, Demongeot J, de Rougemont J: Computer-driven robot for stereotactic surgery connected to $\mathrm{CT}$ scan and magnetic resonance imaging: technological design and preliminary results. Appl Neurophysiol 50: 153-154, 1987.

2) Black PM, Alexander E 3rd, Martin C, Moriatry T, Nabavi A, Wong TZ, Scwartz RB, Jolesz F : Craniotomy for tumor treatment in an intraoperative magnetic resonance imaging unit. Neurosurgery 45: 423-433, 1999.

3) Bobinski RJ, Kokkino AK, Warnick RE, Gaskill-Shipley 
MF, Kormos DW, Lukin RR, Tew JM : Glioma resection in a shared-resource magnetic resonance operating room after optimal image-guided frameless stereotactic resection. Neurosurgery 48: 731-744, 2001.

4) Bobinski RJ, Warnick RE, Gaskill-Shipley MF, Zuccarello M, Loveren HR, Kormos DW, Lukin RR, Tew JM : Intraoperative magnetic resonance imaging to determine the extent of resection of pituitary macroadenomas during transsphenoidal microsurgery. Neurosurgery 49:11331144, 2001.

5) Chinzei K, Miller K: Towards MRI guided surgical manipulator. Med Sci Monit $\quad 7$ : 153-163, 2001.

6) Claudia HM, Scwartz R, Jolesz F, Black PM: Transsphenoidal resection of pituitary adenomas in an intraoperative MRI unit. Pituitary 2: 155-162, 1999.

7) Fichtinger G, DeWeese TI, Patricitu A, Tenace A, Masilu D, Anderson JH, Masamune K, Taylor RH, Stolanovici D : System for robotically assisted prostate biopsy and therapy. Acad Radiol $\mathbf{9 : 6 0 - 7 4 , 2 0 0 2 .}$

8) Hadani M, Spiegelman R, Feldman SZ, Berkenstadt H, Ram Z: Novel, compact, intraoperative magnetic resonance imaging-guided system for conventional neurosurgical operating rooms. Neurosurgery 48: 799-809, 2001.

9) Hall WA, Martin AJ, Liu H, Nussbaum ES, Maxwell RE, Truwit CL: Brain biopsy using high-field strength interventional magnetic resonance imaging. Neurosurgery 44:807-814, 1999 .

10) Hayashi $Y$, Nimura Y, Kitasaka T, Kajita Y, Fujii M, Mizuno M, Wakabayashi T, Yoshida J, Mori K : Surgical-assistance headquarter system based on collaboration of navigation system for image-guided surgery. Int J CARS 5: S406S407, 2010.

11）今井良輔, 安達和彦, 林 雅人, 伊関 洋, 村垣善浩, 鈴木孝司，小西良幸：有限要素解析に基づく腫瘍摘出後 の脳変形シミュレーションの誤差定量評価. J JSCAS 14:276-277, 2012.

12）伊関 洋, 南部恭二郎, 土肥健純, 高倉公朋: ナビゲー ションシステムと手術戦略システムの将来展望. 脳外 誌 7:150-156, 1998.

13）伊関 洋：インテリジェントオペ室・MRI 誘導手術対応 システム. Medix 39:11-16, 2001

14) Jakopec M, Harris SJ, Rodriguezy, Baena F, Gomes P, Cobb J, Davies BL: The first clinical application of a hands-on robotic knee surgery system. Comput Aided Surg 6:329-339, 2001.

15) Jiang Z, Nimura Y, Kitasaka T, Hayashi Y, Ito E, Fujii M, Nagatani T, Kajita Y, Wakabayashi T, Mori K: A method for registering the rotation of virtual and real endoscopic images in flexible neuroendoscopic surgery navigation system. Int J CARS $\quad \mathbf{5}$ : S298-S299, 2010.

16) Kaibara T, Sauders JK, Sutherland GR: Advances in mobile intraoperative magnetic resonance imaging. Neurosurgery 47: 131-138, 2000.

17）梶田泰一, 林雄一郎, 若林俊彦, 森 健策, 吉田 純, 3D ヴァーチャル 画像を用いた術前・術中遠隔手術支援 システムの開発. CI 研究 (in print).

18）梶田泰一，林雄一郎，森 健策，吉田康太，前澤 聡, 水野正明, 若林俊彦, 吉田 純：バーチャルネットワー ク手術室 (Brain THEATER) におけるヘッドクオーター 型脳機能モニタリング遠隔支援システム。機能脳神外 50:38-39, 2011.

19）梶田泰一，藤井正純，前澤 聡，吉田 純：脳腫瘍の画
像誘導手術の現状と今後の展望. No Shinkei Geka 36 ： 443-456, 2008.

20) Kanner AA, Vogelbaum MA, Mayberg MR, Weisenberger JP, Barnett GH : Intracranial navigation by using low-field intraoperative magnetic resonance imaging: preliminary experience. J Neurosurg 97: 1115-1124, 2002.

21) Kinoshita M, Yamada K, Hashimoto N, Koto A, Izumoto S, Baba T, Maruno M, Nishimura T, Yoshimine T: Fibertracking does not accurately estimate size of fiber bundle in pathological conditions : initial neurosurgical experience using neuronavigation and subcortical white matter stimulation. Neuroimage 25: 424-429, 2005.

22) Knauth M, Wirtz CR, Tronnier VM, Aras N, Kunze S, Sartor $\mathrm{K}$ : Intraoperative MR image increase the extent of tumor resection in patients with high grade gliomas. AJNR Am J Neuroradiol 20: 1642-1646, 1999.

23) Kwoh YS, Hou J, Jonckheere EA, Hayathi S : A robot with improved absolute positioning accuracy for stereotactic brain surgery. IEEE Trans Biomed Eng 35:153-160, 1988.

24) Li QH, Zamorano L, Pandaya A, Perez R, Gong J, Diaz F : The application accuracy of the Neuromate robot: A quantitative comparison with frameless and frame-based surgical localization systems. Comput Aided Surg 7:90-98, 2002.

25) Luo X, Feuerstein M, Reichl T, Kitasaka T, Mori K: An application driven comparison of several feature extraction algorithms in bronchoscope tracking during navigated bronchoscopy. Proc. of MICCAI 2010 Workshop: Medical Imaging and Augmented Reality. LNCS 6326: 475-484, 2010.

26) Martin CH, Schwartz R, Jolesz F, Black PM: Transsphenoidal resection of pituitary adenomas in an Intraoperative MRI unit. Pituitary 2: 155-162, 1999.

27) Masuda Y, Ishikawa E, Takahashi T, Ihara S, Yamamoto T, Zaboronok A, Matsumura A: Dual-port technique in navigation-guided endoscopic resection for intraparenchymal brain tumor. Surg Neurol Int 3:352012.

28）森 健策：仮想化内視鏡と手術支援画像作成。日本口 ボット会誌 22：455-459, 2004.

29）森 健策：医用 3 次元画像 医用 3 次元画像の基礎と応 用. 外科 $69: 1-8,2007$.

30) Mori K, Oda M, Egusa T, Jiang Z, Kitasaka T, Fujiwara M, Misawa $\mathrm{K}$ : Automated nomenclature of upper abdominal arteries for displaying anatomical names on virtual laparoscopic images. Proc. of MICCAI Workshop : Medical Imaging and Augmented Reality. LNCS 6326: 353-362, 2010.

31) Nabavi A, Black PM, Gering DT, Westin CF, Mehta V, Pergolizzi RS, Ferrant M, Warfield SK, Hata N, Schwartz RB, Wells WM 3rd, Kikinis R, Joles FA: Serial intraoperative magnetic resonance imaging of brain shift. Neurosurgery 48: 787-798, 2001.

32) Nathoo N, Cavulsoglu MC, Vogelbaum MA, Barnett GH : In touch with robotics: Neurosurgery for the future. Neursurgery 56:421-433, 2005.

33) Nimsky C, Ganslandt O, Cerny S, Hastreiter P, Greiner G, Fahlbusch R: Quantification of, visualization of, and compensation for brain shift using intraoperative magnetic resonance imaging. Neurosurgery 47: 1070-1079, 2000.

34) Nimsky C, Ganslandt O, Kober H, Buchfelder M, Fahrbusch R: Intraoperative magnetic resonance imaging combined with neuronavigation: A new concept. Neurosur- 
gery 48: 1082-1091, 2001.

35) Nimsky C, Ganslandt O, Hastreiter P, Greiner G, Fahlbusch $\mathrm{R}$ : Preoperative and intraoperative diffusion tensor image-based fiber tracking in glioma surgery. Neurosurgery 56:130-137, 2005.

36）大石 誠, 福多真史, 高尾哲郎, 石田 剛, 佐藤光弥, 藤井幸彦：MR 仮想神経内視鏡による微小血管減圧術前 シミュレーションの有用性. No Shinkei Geka 35： 1087-1095, 2007.

37) Prabhu SS, Gasco J, Tummala S, Weinberg JS, Rao G : Intraoperative magnetic resonance inaging-guided tractography with integrated monopolar subcortical functional mapping for resection of brain tumors. J Neurosurg 114: 719-726 2011.

38) Paraskevopoulos D, Unterberg A, Metzner R, Dreyhaupt J, Eggers G, Wirtz CR: Comparative study of application accuracy of two frameless neuronavigation systems: experimental error assessment quantifying registration methods and clinically influencing factors. Neurosurg Rev 34:217-228, 2011.
39) Schulder M, Liang D, Carmel PW : Cranial surgery navigation aided by a compact intraoperative magnetic resonance imager. J Neurosurg 94: 936-945, 2001.

40）鈴木孝司，吉光喜太郎，岡本 淳, 村垣善浩, 伊関 洋： 術室映像 $8 \mathrm{ch}$ 同時録画・解析システムの開発. J JSCAS 14:414-415, 2012 .

41）津坂昌利：ネットワーク技術の基本と 3D PACS 構築の ノウハウ. Innervision 20:69-84, 2005.

42) Wang MN, Song ZJ: Classification and analysis of the errors in neuronavigation. Neurosurgery 68:1131-1145, 2011.

43) Wei J, Wang T, Liu D : A vision guided hybrid robotic prototype system for stereotactic surgery. Int J Med Robotics Compt Assist Surg 7: 475-481, 2011.

44) Zamorano L, Jain QL: Robotics in Neurosurgery: state of the art and future technological challenges. Int $\mathrm{J} \mathrm{Med}$ Robotics Compt Assist Surg 1: 7-22, 2004.

45) Zimmerman M, Krishnan R, Raabe A, Seifert V: Robotassisted navigated neuroendoscopy. Neurosurgery 51: 1446-1452, 2002.

要

旨

ナビゲーション脳神経外科手術の現況と展望

\section{梶田 泰一 森 健策 林 雄一郎 若林 俊彦 吉田 純}

近年, 画像診断技術の進歩により，脳神経外科手術の術前計画を詳細に作成することが可能となっ ている. 特に, 重要な脳機能近傍病変の手術においては, functional magnetic resonance image (fMRI) や tractography を用い脳機能皮質と白質線維を描出し, 病変との位置関係を知り, 最適な手術計画を 検討する必要がある. ニューロナビゲーション技術は，術前計画を確実に実行するために，必要不可 欠となっている，一方, 術中にナビゲーションの位置精度を失うこともしばしば経験し，術者が過度 にナビゲーションを信頼することも危険である．位置精度誤差の原因は，画像の歪み，レジストレー ション等から生じるわずかな誤差の積み重ねであるが, 最大の問題は, 術中の賄液漏出や脳腫瘍切除 に伴う脳偏位である. 術中画像撮像による術前ナビゲーション画像のアップデートがこの問題の最も よい解決法である，術中 MRI 撮影をするには，装置を手術室に導入する困難さがあり，また，安全に 手術をするための制限も多く，広く普及していない，超音波画像は，簡便な撮像法であるが，ナビ ゲーション精度を生かせるほどの画質には至っていない，

今後の二ューロナビゲーションに期待されるものは,まず手術の進行に伴う脳偏位に対し,ナビゲー ション精度を失わない対策である．また，術前，術中に得られる多くの手術支援情報を，ナビゲー ション画像に統合し，術者が直観的に理解できる画像生成技術の開発も有用となる．コンピューター 技術の発展は, 術野内の重要な血管や神経線維の構造物をコンピューターが解釈し, 術者に解剖学的 情報を提供しながら主導的にナビゲートする手術，二ューロナビゲーションが手術計画を超えて手術 スタッフや手術室全体をナビゲートする (environmental navigation) 技術や, cloud 技術を用いたネッ トワーク型ナビゲーション，あるいはナビゲーション画像を使って熟練脳外科医が遠隔手術を支援す るヘッドクォーター型ナビゲーションなどの展開が期待される.

脳外誌 $22 ： 510-518,2013$ 